\title{
POSSIBLE USES OF DATA FROM HOSPITAL DISCHARGE REPORTS
}

Sanja Kocic ${ }^{1,2}$, Dragan Vasiljevic ${ }^{1,2}$, Snezana Radovanovic ${ }^{1,2}$, Svetlana Radevic ${ }^{1,2}$, Ivana Simic Vukomanovic ${ }^{1,2}$ and Natasa Mihailovic ${ }^{1,2}$

${ }^{1}$ Faculty of Medical Sciences, University of Kragujevac, Kragujevac, Serbia

${ }^{2}$ Institute of Public Health, Kragujevac, Serbia

\section{MOGUĆNOSTI KORIŠĆENJA PODATAKA IZ IZVEŠTAJA \\ O HOSPITALIZACIJI}

Sanja Kocić ${ }^{1,2}$, Dragan Vasiljević ${ }^{1,2}$, Snežana Radovanović ${ }^{1,2}$, Svetlana Radević ${ }^{1,2}$, Ivana Simić Vukomanović ${ }^{1,2}$, Nataša Mihailović

${ }^{1}$ Fakultet medicinskih nauka, Univerzitet u Kragujevcu, Kragujevac, Srbija

${ }^{2}$ Institut za javno zdravlje, Kragujevac, Srbija

\section{ABSTRACT}

Almost all countries in the world keep some form of hospital discharge report (HDR). Although there are many variations, every report contains such data as patient demographics, the main cause of hospitalization, comorbidities, the length of stay in hospital and outcome. The advantages of using data obtained from HDRs are numerous: The data from HDRs are already collected in a designated centre and thus easily available and relatively cheap; HDRs contain information for many previous years; they are sometimes more reliable than data obtained through any other method; and finally, they provide a large and representative database. HDRs databases can be connected with other databases using a unified patient identification number. The limitations of using data obtained through HDRs are as follows: inconsistencies in defining and coding diagnoses and applied procedures, common underestimations of comorbidity, limited possible applications in specific studies and partial coverage of inpatient institutions. The prediction that in the future, a growing number of diagnostic and treatment procedures will be performed on an outpatient basis will also limit the use of HDRs. When electronic recordkeeping becomes a practice, we may assume that these data will no longer be needed. There is no perfect model for collection and processing data regarding hospitalized patients. HDRs, with their advantages and disadvantages, currently represent the best way to perceive the size, type, quality and efficiency of the health care services provided to patients at the secondary and tertiary level.

Keywords: Hospital discharge report, comorbidity, diagnostic related groups, health care quality, trend analysis

\section{SAŽETAK}

Gotovo sve države sveta vode IOH u nekom obliku. Iako postoje mnoge varijacije, podatke kao što su: demografski podaci pacijenta, osnovni uzrok hospitalizacije, komorbiditeti, dužina boravka u bolnici (bolesnički dani), ishod, sadrži svaki izveštaj. Prednosti korišćenja podataka iz Izvestaja o hospitalizaciji: Podaci iz IOH-a su već prikupljeni u za to određenom centru, pa su lako dostupni i relativno jeftini, postoje za više godina unazad, ponekad su pouzdaniji od podataka dobijenih na drugi način (mogu da se vide pacijenti koji se ne vide ni u jednoj drugoj bazi podataka), veličina i reprezentativnost baze (smatra da se podaci iz IOH-a odnose na čitavo stanovništvo). IOH bazu je moguce vezati (preko jedinstvenog ID broja pacijenta) sa drugim bazama. Ograničenja korišćenja podataka dobijenih iz Izvestaja o hospitalizaciji: Nedoslednost u definisanju $i$ kodiranju dijagnoza i primenjenih procedura, cesto potcenjivanje komorbiditeta, ograničena mogućnost upotrebe u specifičnim istraživanjima, delimični obuhvat stacionarnih ustanova. Predviđanja da će se u budućnosti sve veći broj dijagnostičkih $i$ terapijskih procedura raditi ambulantno, dodatno će ograničiti upotrebu IOH-a. Kada elektronska evidencija postane praksa, može se pretpostaviti da ovi podaci više neće biti potrebni, s obzirom na količinu i kvalitet informacija koje će se dobijati iz elektronskih izveštaja. Ne postoji savršen model za prikupljanje $i$ obradu podataka hospitalizovanih pacijenata. Izveštaj o hospitalizaciji sa svim svojim prednostima i manama za sada je najbolji način da se sagleda obim, vrsta, kvalitet $i$ efikasnost usluga zdravstvene zaštite koje se pružaju pacijentima na sekundarnom i tercijarnom nivou.

Ključne reči: Izveštaj o hospitalizaciji, komorbiditet, dijagnostički srodne grupe, kvalitet zdravstvene zaštite, analize trendova
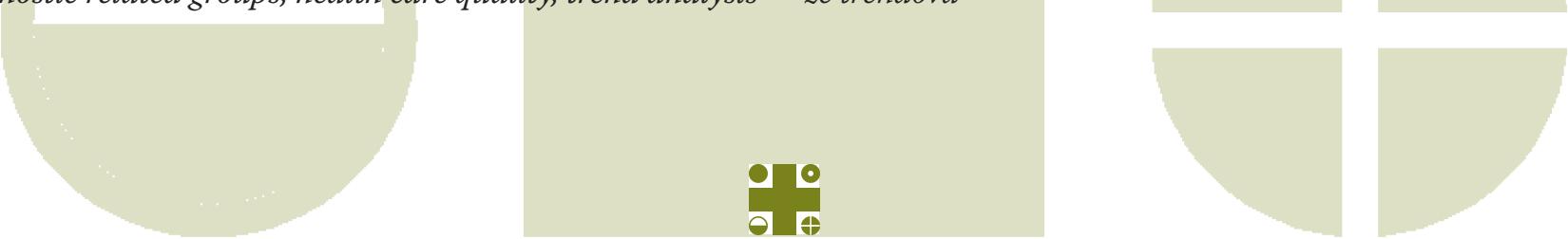


\section{INTRODUCTION}

A hospital discharge report (HDR) is an individual report completed for each patient admitted to a hospital for "episodes of hospitalization" (diagnosis, treatment, rehabilitation and health care) over one night or for more than 24 hours. An episode of hospitalization is a time period calculated from the moment a patient is admitted until the moment he or she is discharged (1).

Almost all countries worldwide keep HDRs in some form. Although there are many variations, every report contains such data as patient demographics, the main cause of hospitalization, comorbidities, length of stay in hospital (hospital days) and outcome. In most countries, the costs of data collection and processing are covered by taxpayers (2).

"Hospital days" represents the number of days a patient spends in an inpatient medical institution for either treatment or medical testing. The number of hospital days represents the number of days spent in hospital, including the day of discharge (3).

"Average length of stay in hospital" refers to the average number of days that patients spent in hospital. It is calculated as a ratio of the total number of hospital days for all hospitalized patients per year to the total number of admissions or discharges (4).

The criteria for evaluating the quality of HDR data bases include the completeness and representativeness of data, consistency over time, accuracy, the existence of data from many previous years, the availability of data and the ability to connect with other databases $(5,6)$.

The most common problems when dealing with HDR databases are inconsistencies in the definitions and coding systems used for diagnoses and applied procedures (7), underestimations of comorbidity (8) and incomplete coverage of inpatient health institutions $(9,10)$.

Although the quality of available data varies, the analysis and the understanding of the variability of the data contained in HDRs is a skill that every doctor-researcher must possess (11).

\section{The use of data from hospital discharge reports}

\section{Comorbidity analysis}

Comorbidity is a term used to describe two or more disorders or illnesses affecting the same patient simultaneously or after one another. Comorbidity also includes possible interactions between a patient's illnesses that can negatively affect the course of each illness (12).

In addition to the basic causes of hospitalization, associated diseases have an impact on treatment outcomes (8). There are several different models for measuring comorbidity, which is important for individual risk assessment and for planning treatment costs and monitoring the quality of provided health services (13). The Charlson Comorbidity Index is the most widely accepted and used index. It includes 19 comorbidities, and each category has a specific comorbidity weight based on the relative risk of death within one year (a higher score indicates a worse prognosis) (14). Specific adapted versions of the Charlson Comorbidity Index can also be used in primary health care to make predictions about the costs of treating patients with chronic illnesses (15).

\section{Diagnosis-related groups}

Diagnosis-related groups (DRGs) represent a method for classifying hospitalized patients into groups that have similar clinical characteristics and require similar consumption of hospital resources. Since the 1990s, most developed countries have introduced a DRG-based payment system for hospitalized patients (11). The primary aim in introducing DRG systems is to increase the efficiency and transparency of hospital services (16). With DRG systems of classification, the costs of diagnostic procedures and treatments are pre-defined within a certain scale for a given DRG group $(17,18)$. The aforementioned cost predictability has been proven in numerous studies that have analysed the costs of treating certain health disorders (19).

The Republic of Serbia has adopted a classification system used in Australia (the Australian Refined Diagnosis Related Groups or AR DRG, version 6.0) that encompasses 698 diagnosis-related groups. It has been used since 2013 (20).

With the gradual transition from the old to the new method of funding hospitals, it is expected that the DRG system will significantly improve reporting and financing in our country by establishing a model for obtaining more accurate and higher-quality patient data that can also be connected with hospital costs data. The primary aim is to shorten the average length of hospitalization and to continuously compare the volume of work among hospitals to divide the available funds between health-care providers in a better and fairer way (20).

\section{Routine monitoring of incidence}

The reliability of HDR data for assessing the incidence of certain diseases that require hospitalization has been proven in several studies. The results obtained in Norway (21), MONIKA (22) and Rochster (23), which examined the sensitivity, positive predicative value and accuracy of HDR data using the stroke register as a gold standard revealed the strong sensitivity (86\%) of HDR databases (21).

\section{Trends analysis}

HDR databases contain data for a number of previous years; consequently, they are suitable for analysing trends in hospitalization and re-hospitalization (24), hospital days $(25,26)$, morbidity, mortality (27) and health-care costs (28).

Mortality trends among hospitalized patients in the United States were analysed by the Center for Disease Control and Prevention using data from HDRs for the years 2000 to 2010. This analysis found that there was an $8 \%$ decrease in mortality, while the number of hospitalized patients increased by $11 \%(29)$. 


\section{Determination of hospital standards}

A standard is the desired level of performance that can be achieved; the current level of performance can be compared against the standard. It represents a valuable means of ensuring and improving the quality of hospital performances. Standards should be measurable, flexible, accepted and adaptable to the needs of a given population (30).

\section{Health system research}

HDR data have been used in studies of national health care systems and in a study of health burden, the economic impact of diseases and the planning of future interventions (31). As a result, after a measles epidemic in Italy in 2002, the MMR vaccine was included in the obligatory vaccination schedule (32). HDR data can also be used in studies of and planning regarding medical interventions that can be performed only in a hospital environment. The efficiency of the system based on the services provided can be examined using information about whether a patient is directly admitted to a given institution or whether he/she is transferred from another (less specialized) institution (15). HDR data are used in analyses that focus on the effects of market competition on increases in hospital costs (33) and in studies analysing the differences in mortality with respect to the educational level of the employees at a given health institution (34). Research on health systems must take into account the racial and ethnic identity of a country's population because these variables can be limiting factors in the usage of certain health services (35).

\section{Evaluation of the quality of health services}

High-quality health care ensures the distribution of available resources in the most effective way to meet the health needs of users in terms of prevention and treatment in the safest possible way and without unnecessary losses. The work quality of inpatient health institutions is expressed through indicators of the quality of the inpatient health institution. These indicators include the mortality rate, the percentage of deaths during the first 48 hours of admission, the average length of hospital treatment, the average number of nurses per occupied hospital beds, the percentage of autopsied patients, the percentage of concordance in clinical and autopsy diagnoses, the percentage of patients readmitted to the intensive care unit during hospitalization and the percentage of patients monitored according to a health care process (36). Most of this information can be obtained from the HDR.

The need to evaluate work quality has arisen from the fact that there is a wide gap between health service expenditures and the relatively poor health status of the population. Patient safety is the main factor considered in the assessment of the work quality and services provided. There are over 200 clearly defined indicators of work quality, and 48 of them are related to safety (37). In some countries, there is a practice of public reporting (via the Internet) on work quality indicators for all levels of institutions. This type of public reporting not only provides necessary information to patients, but it can also be used to improve the work quality of health care institutions (38).
The Healthcare Cost and Utilization Project Quality Indicators (HCUP QIs) represents an approach for measuring the quality of health care using readily available data regarding hospitalized patients. The indicators that are monitored include the outcome measures (mortality and complications), usage and availability (39).

\section{Advantages of using data obtained from hospital discharge reports}

The data from HDRs are already collected in a designated central location and thus are easily available and relatively inexpensive to maintain and access; they contain information from many previous years (40); they are sometimes more reliable than data obtained through other methods (41) (e.g., information about certain patients that is invisible to any other database is available in the HDRs); and finally, the database is large and representative (data from HDRs is considered to refer to whole population). HDR databases can also be linked to other databases through unified patient identification numbers.

\section{Limitations of using data obtained from hospital discharge reports}

The inconsistencies in the defining and coding of diagnoses (7) and applied procedures, the common underestimation of comorbidity (8), the limited applicability to specific studies and the incomplete coverage of inpatient institutions $(9,10)$ represent the limitations of data obtained through HDRs. The predictions that in the future, a growing number of diagnostic and treatment procedures will be performed on an outpatient basis will further limit the use of HDRs. When electronic records become a routine practice, we may assume that HDR data will no longer be needed given the quantity and quality of information that can be obtained from electronic reports. However, the question remains whether or when the routine use of electronic records will occur (42).

\section{CONCLUSION}

There is no perfect model for collecting and processing data regarding hospitalized patients. HDRs with their advantages and disadvantages currently represent the best way to perceive the size, type, quality and efficiency of the health care services provided to patients at the secondary and tertiary level.

\section{REFERENCES}

1. Mihailovic N, Trajkovic G, Simic-Vukomanovic I, Ristic $S$ and Kocic S. Agreement between referral and discharge diagnoses: analysis by groups of international classification of diseases, $\mathrm{X}$ revision. Vojnisanit Pregl 2016; 73 (10): in press. 
2. National Hospital Discharge Survey. USA: Centers for disease control and prevention 24/7. Available from: www.cdc.gov/nchs/nhds.htm

3. Stacionarna zdravstvena zaštita u Republici Srbiji. Zdravstveno-statistički godišnjak Republike Srbije 2013. Beograd: Institut za javno zdravlje Srbije Dr Milan Jovanović Batut; 2014.

4. OECD (2012), "Average length of stay in hospitals", in Health at a Glance: Europe 2012, OECD Publishing. Available from: http://dx.doi.org/10.1787/9789264183896-34-en

5. Schoenman J and Sutton J. Understanding and Enhancing the Value of Hospital Discharge Data. Medical Care Research and Review 2007; 64(4):449-468.

6. Gray BH. and Clement JP. Databases for research on nonprofit health care organizations: Opportunities and limitations. American Behavioral Scientist 2002; 45 (10): 1550-1591.

7. O’Malley KJ, Cook KF, Price MD, Wildes KR, Hurdle JF, Ashton CM. Measuring Diagnoses: ICD Code Accuracy. Health Serv Res 2005; 40(5 Pt 2): 1620-1639.

8. Hall SF. A user's guide to selecting a comorbidity index for clinical research. Journal of Clinical Epidemiology 2006; 59:849-855.

9. National Association of State Health Data Organizations (NAHDO). Consumer-Purchaser Disclosure Project. The state experience in health quality data collection. Washington: National Partnership for Women and Families, 2004.

10. Consumer-Purchaser Disclosure Project. The state experience in health quality data collection. Wachinton DC: National Partnership for Women and Families, 2004.

11. Langenbrunner JC, Cashin C, O’Dougherty S. Designing and implementing provider payment systems: how to manuals. Washington: The World Bank; 2009.

12. DrugFacts: Comorbidity: Addiction and Other Mental Disorders. Bethesda: National Institute on Drug Abuse; 2011.

13. Needham DM, Scales DC, Laupacis A, Pronovost PJ. A systematic review of the Charlson comorbidity index using Canadian administrative databases: a perspective on risk adjustment in critical care research. Journal of Critical Care 2005;20(1):12-9.

14. Charlson M, Wells MT, Ullman R, King F, Shmukler C. The Charlson Comorbidity Index Can Be Used Prospectively to Identify Patients Who Will Incur High Future Costs. PloS one. 2014;9(12):e112479.

15. Laditka J, Laditka S and Probst J. More May Be Better: Evidence of a Negative Relationship between Physician Supply and Hospitalization for Ambulatory Care Sensitive Conditions. Health Serv Res 2005; 40(4):1148-1166.

16. Mathauer I, Wittenbecher F. Hospital payment systems based on diagnosis-related groups: experiences in low and middle-income countries. Bull World Health Organ 2013; 91(10): 746-756.

17. Rankovic A, Rancic N, Jovanovic M, et al. Impact of imaging diagnostics on the budget - Are we spending too much? Vojnosanit Pregl 2013; 70(7): 709-711.
18. Jakovljevic M, Zugic A, Rankovic A, Dagovic A. Radiation therapy remains the key cost driver of oncology inpatient treatment. J Med Econ 2015; 18(1): 29-36.

19. Jakovljevic M, Milovanovic O. Growing Burden of NonCommunicable Diseases in the Emerging Health Markets: The Case of BRICS. Front Public Health 2015; 3: 65.

20. Vodič kroz sistem dijagnostički srodnih grupa . Beograd: Republički fond za zdravstveno osiguranje; 2013.

21. Ellekjaer H, Holmen J. Identification of Incident Stroke in Norway. Hospital Discharge Data Compared With a Population-Based Stroke Register. Stroke 1999; 30: 56-60.

22. Leppälä JM, Virtamo J and Heinonen OP. Validation of stroke diagnosis in the National Hospital Discharge Register and the Register of Causes of Death in Finland. Eur J Epidemiol 1999;15(2): 155-160.

23. Jones SA, Gottesman RF, Shahar E, Wruck L, Rosamond WD. Validity of Hospital Discharge Diagnosis Codes for Stroke: The Atherosclerosis Risk in Communities (ARIC) Study. Stroke 2014; 45(11): 3219-3225.

24. Alper E, O'Malley TA, Greenwald J. Hospital Discharge. Up to Date. 2013 Mar 25 [cited 2013 Apr 15].

Available from: http://www.uptodate.com/contents/hospital-discharge.

25. Qian Li, Zhenqiu Lin, Frederick A Masoudi, at al. National trends in hospital length of stay for acute myocardial infarction in China. BMC Cardiovascular Disorders $2015 ; 15(1): 9$.

26. Weiss AJ (Truven Health Analytics), Elixhauser A (AHRQ). Overview of Hospital Stays in the United States, 2012. HCUP Statistical Brief \#180. October 2014. Agency for Healthcare Research and Quality, Rockville, MD.

Available from: http://www.hcup-us.ahrq.gov/reports/statbriefs/sb180-Hospitalizations-UnitedStates-2012.pdf.

27. Goldberg RJ, Makam RCP, Yarzebski J, McManus DD, Lessard D, Gore JM. Decade Long Trends (2001-2011) in the Incidence and Hospital Death Rates Associated with the In-Hospital Development of Cardiogenic Shock after Acute Myocardial Infarction. Circ Cardiovasc Qual Outcomes 2016. Published online before print February 16, 2016, doi: 10.1161/CIRCOUTCOMES.115.002359.

28. Weiss AJ (Truven Health Analytics), Barrett ML (M.L. Barrett, Inc.), Steiner CA (AHRQ). Trends and Projections in Inpatient Hospital Costs and Utilization, 20032013. HCUP Statistical Brief \#175. July 2014. Agency for Healthcare Research and Quality, Rockville, MD. Available from: http://www.hcup-us.ahrq.gov/reports/ statbriefs/sb175-Hospital-Cost-Utilization-Projections-2013.pdf.

29. Centers for disease control and prevention [homepage on the Internet]. Atlanta: Trends in Inpatient Hospital Deaths: National Hospital Discharge Survey, 2000-2010.

Available from: www.cdc.gov/nchs/data/databriefs/ db118.htm. 
30. Aghaei Hashjin A, Kringos DS, Manoochehri J, Aryankhesal A and Klazinga NS. Development and impact of the Iranian hospital performance measurement program. BMC Health Serv Res 2014; 14: 448.

31. Treadwell JR, Erinoff E and Coates V. How Electronic Clinical Data Can Improve Health Technology Assessment. EGEMS (Wash DC) 2013; 1(2): 1028.

32. Filia A, Brenna A, Panà A, Maggio G, Massari M and Ciofi degli Atti M. Health burden and economic impact of measles-related hospitalizations in Italy in 20022003. BMC Public Health 2007; 7:169.

33. Zwanziger J, Melnick GA, and Bamezai A. Can cost shifting continue in a price competitive environment. Health Econ 2000; 9(3):211-26.

34. Aiken H, Clarke P, Cheund R et al. Educational Levels of Hospital Nurses and Surgical Patient Mortality. JAMA 2003; 290(12)1617-1623.

35. Korenbrot CC, Ehlers S, Crouch JA. Disparities in hospitalizations of rural American Indians. Med Care 2003; 41(5):626-36.

36. Pravilnik o pokazateljima kvaliteta zdravstvene zaštite (“Sl. glasnik RS”, br. 49/2010) (jul 21, 2010).

37. Quan H, Eastwood C, Tess C, Liu M et al. Validity of AHRQ patient safety indicators derived from ICD-10 hospital discharge abstract data (chart review study). BMJ Open 2013; 3:e003716.

38. Drosler SE, Romano PS, Tancredi DJ, et al. International comparability of patient safety indicators in 15 OECD member countries: a methodological approach of adjustment by secondary diagnoses. Health Serv Res 2012; 47(1):275-92.

39. Johantgen M, Elixhauser A, Bali JK, Goldfarb M, Harris DR. Quality indicators using hospital discharge data: state and national applications. Jt Comm J Qual Improv 1998; 24(2):88-105.

40. Kalankesh LR, Pourasghar F, Jafarabadi MA, Khanehdan N. Depiction of Trends in Administrative Healthcare Data from Hospital Information System. Mater Sociomed. 2015; 27(3): 211-144.

41. Quantin C, Benzenine E, Ferdynus C, Sediki M, Auverlot $\mathrm{B}$, Abrahamowicz $\mathrm{M}$ et al. Advantages and limitations of using national administrative data on obstetric blood transfusions to estimate the frequency of obstetric hemorrhages. J Public Health (Oxf) 2013;35(1):147-156.

42. Government Accountability Office (GAO). Health information technology. HHS is taking steps to develop a national strategy. Report to the Chairman, Committee on the Budget, House of Representatives. 2005; GAO-05-628. 